\title{
Helichrysum monizii Lowe: Phenolic Composition and Antioxidant Potential
}

\author{
Sandra Gouveia and Paula C. Castilho*
}

\begin{abstract}
:
Introduction - In Madeira Archipelago there are four endemic Helichyrsum species and three of them are used in the traditional medicine. Helichrysum monizii is a rare endemism with very scarce information available concerning its uses in the local traditional medicine.

Objective - The aim of this work was to study for the first time Helichrysum monizii in terms of its antioxidant capacity and the identification of the phenolic compounds to which that activity is due.

Methodology - Three different methods of extraction were performed and total phenolic and flavonoid contents of extracts were correlated to radical scavenging and antioxidant capacity by DPPH, ABTS, FRAP and $\beta$-carotene assays. An HPLC-DAD-ESI/MS ${ }^{n}$ method was employed for the separation and identification of the phenolic and flavonoid components. Results - The results revealed a high antioxidant potential mainly related to the phenolic profile of the plant. Polar components of methanol extracts of Helichrsyum monizii were detected by a high-performance liquid chromatography/ electrospray ionisation tandem mass spectrometry (HPLC-DAD-ESI/MS ${ }^{n}$ ) method. Thirty-three compounds were identified and 19 of them were identified as quinic acid derivatives.

Conclusions - The high antioxidant potential Helichrysum monizii was for the first time established. Dicaffeoylquinic acids are the main responsible for that activity. Copyright $\odot 2011$ John Wiley \& Sons, Ltd.
\end{abstract}

Keywords: antioxidant; electrospray; flavonoids; Helichrysum; phenolics

\section{Introduction}

The Helichrysum Mill. (family of Asteraceae) genus includes more than 500 species that are widespread around the world. A great number of biological activities are usually attributed to this genus, such as anti-inflammatory, anti-allergic, antioxidant, antimicrobial, cough relief and treatment of cold and wounds (Albayrak et al., 2010).

This genus is represented in Madeira Archipelago (Portugal) by several imported species and by four endemic ones used in folk medicine as well as in gardening as decorative shrubs. These four endemic species are: Helichrysum devium Johns., Helichrysum melaleucum Rchb. Ex Holl, Helichrysum obconicum DC. and Helichrysum monizii Lowe. Our recent work has been focused on the study of these endemic species. The three first plants mentioned above are well known for their use in traditional medicine with different purposes (Gouveia and Castilho, 2009, 2010). The study of the endemic population of Helichrysum subspecies would not be complete without Helichrysum monizii Lowe, nowadays an extremely rare plant that inhabits only a few cliffs on south coast of Madeira. According to expert botanists, only about six specimens survive in the wild, in locations that are very difficult to access. To overcome the threat of extinction, Madeira Botanical Garden recently developed a programme for greenhouse reproduction of this plant and has kindly provided us with a small sample of plant material for this investigation.

Owing to its scarcity, Helichrysum monizii is not considered a useful plant and there is no scientific research in terms of its biological activity and its phenolic composition. The investigation of these points comprises the main novelty and interest of this work. Plant phenolic compounds are plant secondary metabolites. They possess the capacity to scavenge free radicals and can interact with biological systems in order to prevent diseases associated with lipid oxidation (Katalinic et al., 2010). The consumption of antioxidants is believed to prevent or reduce the risk of lipid oxidation associated with a high number of major health problems and also food deterioration. The search for natural sources of antioxidants with low cytotoxicity has increased dramatically over the years. Therefore, the aims of this work were to evaluate the total phenolic and flavonoid content, to evaluate the antioxidant capacity of the methanolic extracts and to establish its phenolic composition by HPLC-DAD-ESI/MS ${ }^{n}$, in order to compare this plant with the other endemic subspecies.

\section{Experimental}

\section{Chemicals and standards}

The following reagents were purchased from Merck (Darmstadt, Germany): potassium persulphate (99\%), sodium chloride (99.5\%), disodium phosphate dodecahydrated (99\%), glacial acetic acid (100\%), sodium carbonate (р.a.) and ferrous sulphate heptahydrate (99\%). 2,2-Diphenyl-1-picrylhydrazyl (DPPH) (> 95\%), Trolox ( $\geq 99.8 \%, H P L C)$, 2,2'-azinobis-(3-ethylbenzthiazoline-6-sulphonic acid) (ABTS) ( $\geq 99 \%$, HPLC), 2,4,6-tri(2-pyridyl)-s-triazine (TPTZ) ( $\geq 99.0 \%$, TLC), $\beta$-carotene ( $\geq 97 \%, U V)$, Tween 40 and Folin-Ciocalteu's phenol reagent were purchased from

\footnotetext{
* Correspondence to: P. C. Castilho, Centro de Química da Madeira, CCCEE, Universidade da Madeira, Campus da Penteada, 9000-390 Funchal, Portugal. E-mail: castilho@uma.pt

Centro de Química da Madeira, CCCEE, Universidade da Madeira, Campus da Penteada, 9000-390 Funchal, Portugal
} 
Fluka (Lisbon, Portugal). Potassium chloride (> 99.5\%), gallic acid (99\%, HPLC), potassium acetate (р.a.), rutin ( $\geq 98 \%$, HPLC) and ferric chloride hexahydrate (97-100\%) were purchased from Panreac (Barcelona, Spain); potassium dihydrogen phosphate $(99.5 \%)$, aluminium chloride $(98 \%)$ and sodium acetate trihydrate (pure) were purchased from Riedel-de Haën (Hanover, Germany).

All solvents used for plant extraction were AR-grade, purchased from Fisher (Lisbon, Portugal). HPLC-MS-grade acetonitrile (99.9\%, LabScan, Gliwice, Poland) and ultra-pure water (Milli-Q Waters purification system, EUA) were used for HPLC analysis.

Stock solutions of standard compounds $(100 \mu \mathrm{g} / \mathrm{mL})$ were prepared in ethanol for HPLC-DAD-ESI/MS ${ }^{n}$ identification and stored in a refrigerator at $-20^{\circ} \mathrm{C}$ until use. Standards used were: $p$-coumaric acid (>99\%), caffeic acid (> 99\%), protocathecuic acid (> 99\%) from Extrasynthese (Lyon, France), and 5-O-caffeoylquinic acid (99\%) from Acros Organics (Geel, Belgium); 1,3-O-dicaffeoylquinic acid, 1,5-O-dicaffeoylquinic acid, 3,4-Odicaffeoylquinic acid, 3,5-O-dicaffeoylquinic acid, 4,5-O-dicaffeoylquinic acid and 3,4,5-O-tricaffeoylquinic acid ( $>98 \%$ by HPLC for all) were obtained from Chengdo Biopurify Phytochemicals Ltd China (Sichuan, China).

\section{Plant material and sample preparation}

A sample of Helichrysum monizii was obtained from Madeira Botanical Garden collection. The aerial parts were dried (at room temperature and protected from direct sunlight) and ground to fine powder in a mechanic grinder. Then the powdered plant material was extracted by three different methods:

(1) ultrasound-assisted solvent extraction - plant material $(1 \mathrm{~g})$ was extracted with methanol $(25 \mathrm{~mL})$ using a sonicator Bandelin Sonorex (Germany) at $35 \mathrm{kHz}$ and $200 \mathrm{~W}$ for $60 \mathrm{~min}$ at room temperature.

(2) solid-liquid extraction - plant material $(1 \mathrm{~g})$ was extracted with methanol $(25 \mathrm{~mL})$ at room temperature for $24 \mathrm{~h}$.

(3) Soxhlet extraction - plant material ( $3 \mathrm{~g}$ ) was extracted using a Soxhlet-type extractor with methanol $(200 \mathrm{~mL})$ at $60^{\circ} \mathrm{C}$ for $4 \mathrm{~h}$.

In all cases the solutions were filtered and concentrated under reduced pressure in a rotary evaporator $\left(40^{\circ} \mathrm{C}\right)$ and kept in the dark at $4^{\circ} \mathrm{C}$ until tested.

\section{Total phenolic content}

The total content of phenolic compounds of the extracts was determined following the Folin-Ciocalteu method (Zheng and Wang, 2001) with some modifications. Plant extracts were dissolved in methanol to yield a concentration $(\mathrm{w} / \mathrm{v}) 10 \mathrm{mg} / \mathrm{mL}$. Each sample solution $(50 \mu \mathrm{L})$ was mixed with $1.25 \mathrm{~mL}$ of Folin-Ciocalteu reagent (diluted 1:10 fold) and $1 \mathrm{~mL}$ of $7.5 \%$ sodium carbonate solution. The mixture was incubated for $30 \mathrm{~min}$ at room temperature and then absorbance was measured at $765 \mathrm{~nm}$. The final results were expressed as gallic acid equivalents per 100 gram of dried plant (mg GAE/100 g dried plant).

\section{Total flavonoid content}

Total flavonoid content was measured using a modified method (Akkol et al., 2008). Briefly, $10 \mathrm{mg}$ of extract was dissolved in $5 \mathrm{~mL}$ of methanol. In a $10 \mathrm{~mL}$ test tube, $0.5 \mathrm{~mL}$ of sample solution, $1.5 \mathrm{~mL}$ of methanol, $2.8 \mathrm{~mL}$ of water, $0.1 \mathrm{~mL}$ of potassium acetate $(1 \mathrm{M})$ and $0.1 \mathrm{~mL}$ of aluminium chloride (10\% in methanol) were mixed. The decrease in absorbance was measured at $415 \mathrm{~nm}$ after incubation at room temperature for $30 \mathrm{~min}$. The total flavonoid content was expressed as milligrams of rutin equivalent per 100 gram of dried sample (mg RUE/100 g dried plant).

\section{$\mathrm{ABTS}^{++}$radical scavenging activity}

The method of decolourisation of free radical ABTS ${ }^{+}$used was a modified version of that initially reported by Re et al. (1999). The ABTS.+ radical was prepared by reacting $50 \mathrm{~mL}$ of $2 \mathrm{mM} \mathrm{ABTS}$. $^{+}$solution with $200 \mu \mathrm{L}$ of $70 \mathrm{mM}$ potassium persulphate solution. This mixture was kept in the dark for $16 \mathrm{~h}$ at room temperature. This solution was stable in this form for two days (Re et al., 1999). For each analysis the $\mathrm{ABTS}^{+}$solution was diluted with $\mathrm{pH} 7.4$ phosphate buffered saline (PBS) solution to an initial absorbance of $0.700 \pm 0.021$ at $734 \mathrm{~nm}$. This solution was freshly prepared for each analysis. For the assessment of the radical scavenging activity, an aliquot of $100 \mu \mathrm{L}$ methanolic solution with a concentration (w/v) of $10 \mathrm{mg} / \mathrm{mL}$ was added to $1.8 \mathrm{~mL}$ of $\mathrm{ABTS}^{+}$solution and the absorbance decrease, at a $734 \mathrm{~nm}$, was recorded during $6 \mathrm{~min}$. Results were expressed in terms of micromoles Trolox equivalent per 100 grams of dried plant antioxidant capacity ( $\mu$ mol equiv. Trolox $/ 100 \mathrm{~g}$ dried plant).

\section{DPPH radical scavenging activity}

The DPPH method was executed according to the method of Gordon et al. (2001), introducing some modifications. Briefly, $100 \mu \mathrm{L}$ of the methanolic solutions $(10 \mathrm{mg} / \mathrm{mL})$ were added to $3.5 \mathrm{~mL}$ of a $0.06 \mathrm{mM}$ methanol DPPH radical solution. The decrease in absorbance at $516 \mathrm{~nm}$ was measured every minute during $30 \mathrm{~min}$, in the dark. The DPPH radical scavenging effect of the extracts was expressed, based on the Trolox calibration curve as $\mu \mathrm{mol}$ Trolox equivalent per $100 \mathrm{gram}$ of dried plant ( $\mu \mathrm{mol}$ equiv. Trolox $/ 100 \mathrm{~g}$ dried plant).

\section{Ferric reducing activity}

The ferric reducing ability of the extracts was assessed based on the ferric reducing activity (FRAP assay) assay (Benzie and Strain, 1996). FRAP reagent was prepared daily by mixing $2.5 \mathrm{~mL}$ of solution ferric trichloride hexahydrate $(20 \mathrm{mM}), 2.5 \mathrm{~mL}$ of solution TPTZ $(10 \mathrm{mM}$ in $40 \mathrm{mM}$ of hydrochloric acid) and $25 \mathrm{~mL}$ of acetate buffer $0.3 \mathrm{M}(\mathrm{pH} 3.6)$ and incubating at $37^{\circ} \mathrm{C}$. The extracts were dissolved in methanol to yield a final concentration of $1 \mathrm{mg} / \mathrm{mL}$. For each analysis, $30 \mu \mathrm{L}$ of methanolic solution was added to $180 \mu \mathrm{L}$ of distilled water and $1.8 \mathrm{~mL}$ of FRAP solution. The increase in absorbance was recorded at $593 \mathrm{~nm}$ in $15 \mathrm{~s}$ intervals, during $30 \mathrm{~min}$ at $37^{\circ} \mathrm{C}$. The FRAP results were expressed as mmol Fe(II) sulphate heptahydrate per $\mathrm{mg}$ of dried plant [mmol Fe(II)/mg dried plant].

\section{$\beta$-Carotene bleaching assay}

The method described in literature (Siddhuraju and Becker, 2003) was applied with some modifications. Briefly, $2 \mathrm{~mL}$ of $\beta$-carotene solution $0.2 \mathrm{mg} / \mathrm{mL}$ in chloroform was added to a round-bottom flask, containing $0.04 \mathrm{~mL}$ of linoleic acid and $200 \mathrm{mg}$ of Tween 40 . The chloroform was removed by evaporation using nitrogen and then $50 \mathrm{~mL}$ of oxygenated ultrapure water, obtained by bubbling air through the water for $15 \mathrm{~min}$, was added. The mixture was vigorously shaken. The resulting emulsion was freshly prepared before each experiment. Stock solutions of the extracts were prepared in ethanol to yield a final concentration of $1 \mathrm{mg} /$ $\mathrm{mL}$. An aliquot of $250 \mu \mathrm{L}$ of the $\beta$-carotene-linoleic acid emulsion was distributed in each of the wells of the 96-well microtitre plates and $30 \mu \mathrm{L}$ of the samples solutions were added. An equal amount of ethanol was used as control. The samples were then subjected to thermal autoxidation at $45^{\circ} \mathrm{C}$ for $210 \mathrm{~min}$. The solution's absorbance was measured at $490 \mathrm{~nm}$, at $15 \mathrm{~min}$ intervals. The antioxidant activity $(A A)$ of each sample was evaluated in terms of the bleaching of $\beta$-carotene using the following equation: $A A(\%)=\left(1-A_{0}-A_{t} / A_{0}^{\prime}-A_{t}^{\prime}\right)^{*} 100$, where $A_{0}$ and $A_{0}^{\prime}$ are the absorbance values measured at zero incubation time for the test and control respectively and $A_{t}$ and $A_{t}^{\prime}$ are the corresponding absorbance values measured after incubation for $210 \mathrm{~min}$.

\section{HPLC-DAD-ESI/MS ${ }^{n}$ analysis}

Liquid chromatography. Stock solutions with concentrations $(w / v)$ of $5 \mathrm{mg} / \mathrm{mL}$ were prepared by dissolving each dried extract in initial HPLC mobile phase (acetonitrile:water, 20:80, v/v). These solutions were 
filtered through $0.45 \mathrm{~mm}$ Nylon micropore membranes prior to use and $10 \mathrm{~mL}$ were injected for HPLC-DAD-ESI/MS ${ }^{n}$ analysis. Three independent assays were performed for each sample.

The HPLC analysis was performed on a Dionex ultimate 3000 series instrument (California, EUA) coupled to a binary pump, a diode-array detector (DAD), an autosampler and a column compartment. Samples were separated on a Phenomenex Gemini $C_{18}$ column $(5 \mu \mathrm{m}$, $250 \times 3.0 \mathrm{~mm}$ i.d.) with a sample injection volume of $10 \mu \mathrm{L}$. The mobile phase consisted of acetonitrile (A) and water:formic acid (100:0.1, v/v) (B). A gradient programme was used as follows: $20 \% \mathrm{~A}$ (0 min), $25 \% \mathrm{~A}$ (10 min), 25\% A (20 min), 50\% A (40 min), 100\% A (42-47 min), 20\% A $(49-55 \mathrm{~min})$. The mobile phase flow rate was $0.4 \mathrm{~mL} / \mathrm{min}$; the chromatogram was recorded at $280 \mathrm{~nm}$ and $350 \mathrm{~nm}$ and spectral data for all peaks were accumulated in the range of $190-400 \mathrm{~nm}$. Column temperature was controlled at $30^{\circ} \mathrm{C}$.

Mass spectrometry. For HPLC-ESI/MS ${ }^{n}$ analysis, a model 6000 ion trap mass spectrometer (Bruker Esquire, Bremen, Germany) fitted with an ESI source was used. Data acquisition and processing were performed using Esquire control software. Negative ion mass spectra of the column eluate were recorded in the range $\mathrm{m} / \mathrm{z} 100-1000$ at a scan speed of $13000 \mathrm{Da} / \mathrm{s}$. High-purity nitrogen $\left(\mathrm{N}_{2}\right)$ was used both as drying gas at a flow of $10.0 \mathrm{~mL} / \mathrm{min}$ and as a nebulising gas at a pressure of $50 \mathrm{psi}$. The nebuliser temperature was set at $365^{\circ} \mathrm{C}$ and a potential of $+4500 \mathrm{~V}$ was used on the capillary. Ultra-high-purity helium $(\mathrm{He})$ was used as collision gas at a pressure of $1 \times 10^{-5} \mathrm{mbar}$ and the collision energy was set at $40 \mathrm{~V}$.

The acquisition of $\mathrm{MS}^{n}$ data was made in auto $\mathrm{MS}^{n}$ mode, with an isolation width of $4.0 \mathrm{~m} / \mathrm{z}$. For $\mathrm{MS}^{n}$ analysis, the mass spectrometer was scanned from 10 to $1000 \mathrm{~m} / z$ with a fragmentation amplitude of $1.0 \mathrm{~V}$ $\left(\mathrm{MS}^{n}\right.$ up to $\mathrm{MS}^{4}$ ) and two precursor ions.

\section{Statistical analysis}

All measurements were performed in triplicates and results are expressed as mean \pm SD. Significant differences in antioxidant activity, total phenolic and flavonoid content of the different extracts were determined using one-way ANOVA. The statistical probability was considered to be significantly different at the level of $p<0.05$.

\section{Results and Discussion}

\section{Extraction yield, total phenolic content and total flavonoid content}

Three different methods of extraction, based on liquid-solid extractions, were used to obtain methanolic extracts of Helichrysum monizii. The yield percentages obtained for each of the procedures are shown in Table 1. The values were 3.56\% (maceration), $12.49 \%$ (ultrasonication) and $16.0 \%$ (Soxhlet extraction). Soxhlet extraction showed a higher, but not remarkably higher, yield (ca. $4 \%$ higher) than the ultrasonication extraction, considering that this last one uses a smaller amount of sample, volume of solvent and time of extraction. Soxhlet extraction has the disadvantage of possible deterioration of thermolabile compounds (Kaufman et al., 1999). Nevertheless, we compared the phenolic and flavonoid composition and evaluated the antioxidant capacity of extracts from Helichrysum monizii obtained by the three methods. The extract obtained by the Soxhlet method showed the higher phenolic content at $369.35 \pm 8.15 \mathrm{mg} \mathrm{GAE} / 100 \mathrm{~g}$, followed by the ultrasonication and maceration extraction gave the lowest phenolic content. The total flavonoid content revealed the same relative order: maceration $(4.69 \pm 0.0139 \mathrm{mg} R U E / 100 \mathrm{~g})<$ ultrasonication extraction $(17.31 \pm 0.52 \mathrm{mg}$ RUE $/ 100 \mathrm{~g})<$ Soxhlet $(19.50 \pm 0.70 \mathrm{mg}$ RUE/100 g).
These orders of values, found in both types of compounds, are related to the capacity of the extraction method to release these substances. Soxhlet extraction provided the highest total phenolic and flavonoid contents, which can be explained by the fact that higher temperatures of extraction affect the integrity of the cell wall and therefore induce a higher recovery of metabolites (Li et al., 2006). However, as the HPLC-MS ${ }^{n}$ methods of analysis demonstrated, some of the components are degraded by high temperature and some artefacts are present in the chromatogram. Maceration, as expected, was proven to be the less effective method of extraction.

\section{Antioxidant assays}

The antioxidant properties of natural products, such as plant extracts, are due to the nature of the bioactive compounds and sometimes to synergistic effects between them. However, the establishment of the contribution of each individual component to the total antioxidant activity is difficult and time consuming. The common procedure is to measure the total antioxidant capacity of the whole sample.

There are several methodologies widely used and, in this work, we determined the free radical scavenging capacity of Helichrysum monizii using ABTS and DPPH methods, and their reducing capacity by the FRAP method and the $\beta$-carotene bleaching assay. The use of several methods to measure antioxidant activity may seem a redundancy, but since different authors used various methods, comparison of properties becomes easier if a large set of data is available.

\section{$\mathrm{ABTS}^{++}$radical scavenging activity}

The cation radical $\mathrm{ABTS}^{+}$consumption due to the Helichrysum monizii samples was measured using the calibration curve for Trolox $\left(8-270 \mu \mathrm{m}, R^{2}=0.9995\right)$. The ABTS values of Helichrysum monizii samples extracted by different methods are presented in Table 1. All extracts showed the capacity to neutralise the radical cation $\mathrm{ABTS}^{+}$but at different levels significantly different at $p<0.05$. The lowest activity was obtained from the maceration extraction with a value of $3167.73 \pm 1.42 \mu \mathrm{mol}$ equiv. Trolox $/ 100 \mathrm{~g}$, followed by the ultrasonication and Soxhlet extraction with values of $10856.12 \pm 9.44$ and $25023.93 \pm 79.93 \mu \mathrm{mol}$ equiv. Trolox/100 g, respectively.

\section{DPPH radical scavenging activity}

The purple solution of the free radical DPPH gives a characteristic absorption at $516 \mathrm{~nm}$ which decreases by reaction with samples rich in electron or hydrogen donors. The slower the decrease in absorbance, at the same concentration, the higher the antioxidant capacity of the extract.

A large range of activity was obtained by the DPPH method with values varying from $9917.63 \pm 33.63 \mu \mathrm{mol}$ equiv. Trolox $/ 100 \mathrm{~g}$ (maceration) to $46176.43 \pm 3.78 \mu \mathrm{mol}$ equiv. Trolox $/ 100 \mathrm{~g}$ (Soxhlet extraction). The same order of activity observed in the ABTS method was found in the DPPH method, confirmed by the very good correlation $\left(R^{2}=1\right)$ between these two methods. Still, the ABTS values are lower than those obtained from the DPPH assay. This can probably be attributed to the fact that the ABTS. ${ }^{+}$solution is more easily decolourised by compounds with high molecular weights such as tannins (Siddhuraju, 2007). Nevertheless, the ABTS assay has the advantage of the working solution being soluble in 
Table 1. Helichrysum monizii experimental determinations of total phenolic and flavonoid content and antioxidant capacity against ABTS, DPPH, FRAP and $\beta$-carotene

\section{Helichrysum monizil}

Extraction yield (\%)

Total phenolic content (mg GAE/100 g dried plant)

Total flavonoids content (mg RUE/100 g dried plant)

ABTS ( $\mu \mathrm{mol}$ equiv. Trolox $/ 100 \mathrm{~g}$ dried plant)

DPPH ( $\mu$ mol equiv. Trolox/100 g dried plant)

FRAP [mmol $\mathrm{Fe}(\mathrm{II}) / \mathrm{mg}$ dried plant]

$\beta$-Carotene (\%) $(1 \mathrm{mg} / \mathrm{mL})$
Methanolic extraction

Maceration
3.56
$131.341 \pm 3.32$
$4.686 \pm 0.0138$
$3167.73 \pm 1.42$
$9917.63 \pm 33.63$
$24352.0 \pm 35.2$
$3.87 \pm 1.31$

Ultrasonication

12.49

$170.948 \pm 5.94$

$17.312 \pm 0.516$

$10856.12 \pm 9.44$

$22576.88 \pm 54.14$

$35854.4 \pm 64.3$

$5.36 \pm 0.08$

Soxhlet
16.00
$369.346 \pm 8.15$
$19.489 \pm 0.70$
$25023.74 \pm 79.93$
$46176.43 \pm 31.78$
$38014.5 \pm 396.9$
$7.86 \pm 0.41$

aqueous and organic solvents, at a large range of $\mathrm{pH}$ values, and the reaction time is lower than the DPPH assay. The benefit of employing the DPPH assay is due to the higher stability of the DPPH radical and its commercial form being ready to use.

\section{FRAP assay}

The FRAP assay measures the antioxidant properties of any sample based on its reducing ability. It is a method based on the colour change where the yellow ferric-tripyridyltriazine complex is reduced to the blue ferrous complex. This reaction is $\mathrm{pH}$-dependent (ideal $\mathrm{pH}$ 3.6). The FRAP results are expressed

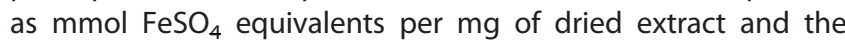
results show that the Soxhlet extraction, once more, provided the extract with higher antioxidant capacity with a FRAP value of $38014.5 \pm 396.9 \mathrm{mmol}$ Fe (II)/mg. The values obtained for the other extracts (Table 1$)$ are significantly different $(p<0.05)$, but not as different as observed in the ABTS and DPPH assays.

Based on these results, it is possible to infer that the three types of extraction studied are effective in the recuperation of compounds with good reducing capacity and good electron donors. The FRAP values showed a reasonable correlation with the ABTS and DPPH data, meaning that compounds present in the samples with radical scavenge capacity also have some reducing capacity.

\section{$\beta$-Carotene bleaching assay}

In this assay, the peroxyl radicals formed when linoleic acid is oxidised attack the highly unsaturated $\beta$-carotene molecules that consequently undergo fast decolourisation (Katalinic et al., 2010). The presence of antioxidants in the sample will reduce the oxidation of $\beta$-carotene. According to some authors, this process reaches a plateau phase after 90-120 min of reaction time (Parejo et al., 2002). However, for Helichrysum monizii samples a reaction time of $210 \mathrm{~min}$ was necessary.

Several concentrations $(10-1 \mathrm{mg} / \mathrm{mL})$ were studied for each extract. None of the samples completely inhibited the $\beta$-carotene oxidation and the most powerful extract was that obtained from the Soxhlet extraction. For a concentration of $10 \mathrm{mg} / \mathrm{mL}$ the inhibition of $\beta$-carotene was similar to all samples, despite of being statistically different (Table 1). For the lowest concentration $(1 \mathrm{mg} / \mathrm{mL})$, the Soxhlet extract presented a higher antioxidant capacity $(7.86 \pm 0.41 \%)$ followed by the ultrasonication extraction $(5.36 \pm 0.08 \%)$ and maceration $(3.87 \pm 1.31 \%)$. These data revealed that the extract obtained by Soxhlet extraction has a composition with higher capacity to prevent the oxidation of lipids and can be used as preservatives to delay or limit lipids oxidation.

The ABTS and DPPH results were poorly correlated with the $\beta$-carotene values, probably due to a weak solubility in the twophase medium of $\beta$-carotene reaction of the most active compounds against ABTS and DPPH radicals.

\section{Correlations between the total phenolic and flavonoid content and antioxidant assays}

It is well known that the antioxidant activity of a plant extract largely depends on both the composition of the extract and the test system. The antioxidant activity can be influenced by a large number of factors, and cannot be fully evaluated by one single method due to the various mechanisms of antioxidant action. Table 2 shows the correlations (linear regression coefficients, $R^{2}$ ) between the total flavonoid contents (TFC), total phenolic contents (TPC) and the four antioxidant assays results for Helichrysum monizii samples. The radical scavenging methods (ABTS and DPPH) showed a satisfactory correlation with the TFC $\left(R^{2}\right.$ ca. 0.72$)$ and a very good correlation $\left(R^{2}\right.$ ca. 0.96$)$ with the TPC, indicating that most phenolic compounds extracted from Helichrysum monizii were capable of reacting in both methods.

The antioxidant capacity of phenolic acid derivatives is normally dependent on the number of hydroxyl and methoxyl groups linked to the aromatic ring. For example, polyphenols are more effective than the monophenols, and cinnamic acid derivatives display higher antioxidant capacity than their benzoic counterparts (Kim and Lee, 2004). The radical scavenging capacity of flavonoids is structure-dependent (Silva et al., 2002), the presence of a catechol group in the B-ring being essential for a good scavenging activity. The conjugation of the B-ring is also important to ensure electron-delocalisation. This

Table 2. Correlations values $\left(R^{2}\right)$ between the antioxidant assays results and total flavonoid content (TFC) and total phenolic content (TPC) of Helichrysum monizii samples

$\begin{array}{lcc}R^{2} & \text { TFC } & \text { TPC } \\ \text { ABTS } & 0.7184 & 0.9624 \\ \text { DPPH } & 0.7210 & 0.9612 \\ \text { FRAP } & 0.9999 & 0.5413 \\ \beta \text {-Carotene } & 0.8891 & 0.7105\end{array}$


structure-activity dependency can be the explanation for the observed correlation decrease observed.

The opposite was found with the FRAP assay (Table 2). FRAP results were extremely well correlated $\left(R^{2}=0.9999\right)$ to the total flavonoid content but poorly with the total phenolic content $\left(R^{2}=0.5413\right)$. This result was somehow unexpected since the Folin-Ciocalteu method used for TPC determination is based on the reducing properties of the sample. However, the correlation between antioxidant assays and TPC is usually established for TPC values obtained from different samples obtained by the same extraction method; therefore variations are quantitative rather than qualitative. In the present work, the TFC and TPC values we are plotting against FRAP results were obtained from different methods of extraction, affecting different types of compounds: for instance, Soxhlet extraction yielded $4 \%$ more extract than ultrasonication but the TPC in it is more than double, while the TFC increased in only $2 \%$ (Table 1 ). The FolinCiocalteu assay is not specific for particular groups of phenolic compounds and is affected by interfering substances such as organic acid, sugars and organic non-phenolic acids (Singleton et al., 1999). It may happen that these substances are good radical scavengers but poor reducing agents, thus leading to nonlinear results.

The most relevant observation concerning the antioxidant properties of $\mathrm{H}$. monizzi is that its methanol extract is at least 10 times more active, in all performed assays, than those of the other three Helichrysum subspecies we have studied using exactly in the same conditions (data to be published elsewhere). Also, in a study of 112 species (Cai et al., 2004) only six showed higher activity on the ABTS assay, and those were aqueous extracts rich in flavonols and tannins, considered to have higher individual activity than hydroxycinnamic acids.

\section{HPLC-DAD-ESI/MS ${ }^{n}$ analysis}

Considering the high antioxidant capacity of the methanolic extracts from Helichrysum monizii, its phenolic composition was investigated by a HPLC-DAD-ESI/MS ${ }^{n}$ method. The optimised HPLC conditions were obtained after evaluating several parameters, such as mobile phase (composition and $\mathrm{pH}$ ), sample concentration, volume of injection and ionisation parameters. The conditions that showed the best separation and resolution were those described above.

Despite Soxhlet extract exhibiting the highest antioxidant capacity in the in vitro antioxidant assays, the HPLC-DAD-ESI/ $M^{n}$ screening of the extract obtained by ultrasonication displayed a chromatogram with better resolution and fragmentation patterns. As mentioned before, ultrasonication was an efficient method for extracting active components (which extraction by maceration was not capable to do) without the risk of thermal degradation associated with Soxhlet extraction. Thus, the ultrasonication extract was selected to run further analysis for separation and identification of the phenolic composition of Helichrysum monizii.

Thirty-seven peaks were detected and 33 were characterised. Most of them showed typical hydroxycinnamic acid UV absorptions $\left(\lambda_{\max } 230-240,300\right.$ sh. 320-340 nm) suggesting that the large percentage of the components are hydroxycinnamic conjugates (Mabry et al., 1970). Seven components were undoubtedly identified by comparison with commercially available standards: characterisation of the peaks was achieved by comparison of the HPLC retention time, UV and mass spectra of standard solutions. Since there are no standard compounds for the majority of the peaks, the proposed structure of the other compounds was based mainly on the $\mathrm{MS}^{n}$ fragmentation mechanisms and complemented

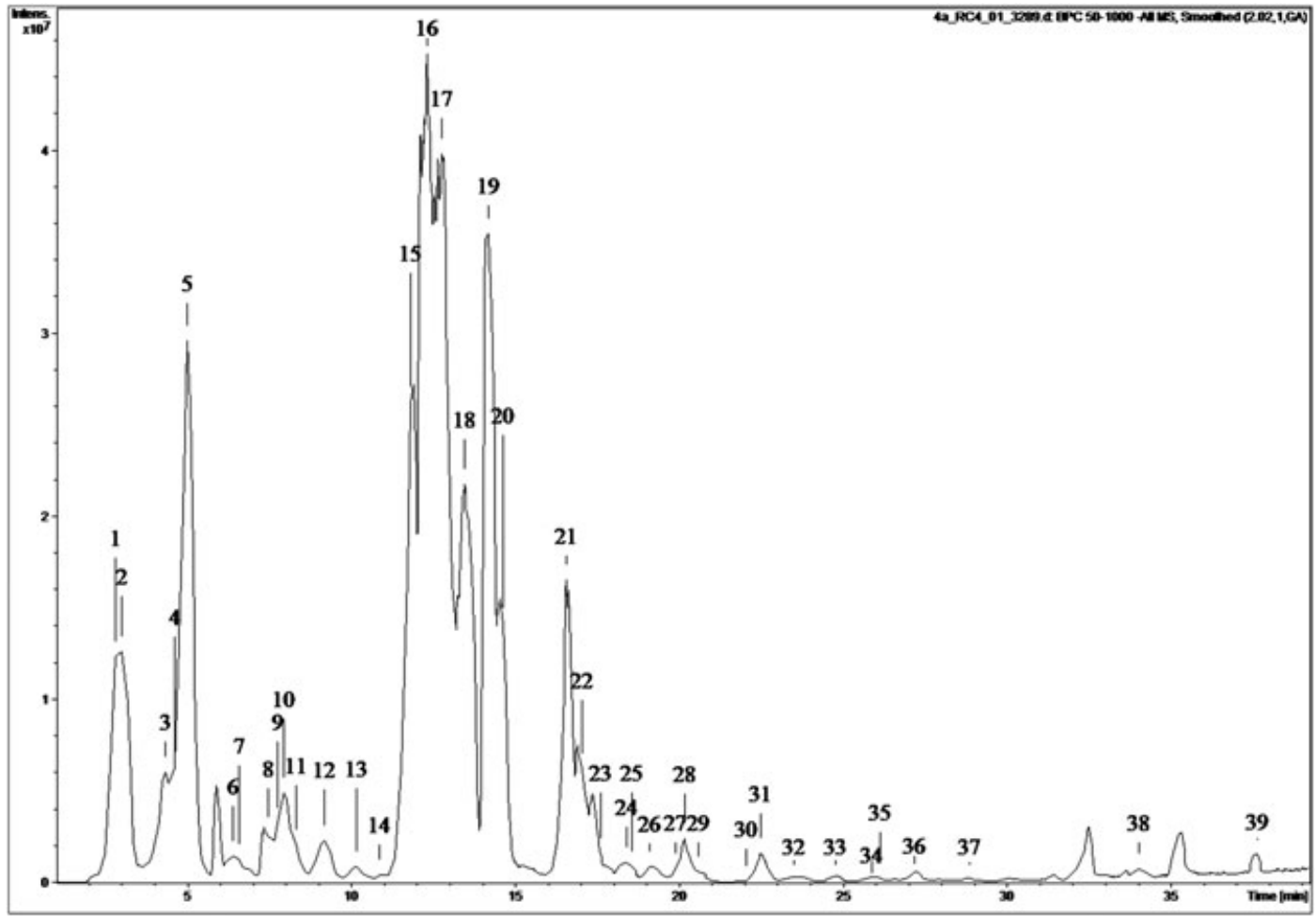

Figure 1. HPLC-DAD-ESI/MS ${ }^{n}$ analysis of the methanolic extract of Helichrysum monizii total aerial parts; LC-MS negative ion ESI-MS base peak chromatogram. 
Table 3. Characterisation of phenolic compounds of the methanolic extract of total aerial parts from Helichrysum monizii by HPLC-DAD-ESI/MS ${ }^{n}$

\begin{tabular}{|c|c|c|c|c|c|}
\hline No. & $t_{\mathrm{R}}(\min )$ & UV $\lambda_{\max }(\mathrm{nm})$ & {$[\mathrm{M}-\mathrm{H}]^{-} \mathrm{m} / \mathrm{z}$} & HPLC-DAD-ESI/MS ${ }^{n} \mathrm{~m} / z$ (\% base peak) & Assigned identity \\
\hline 1 & 2.9 & 294,324 & 683 & $\begin{array}{l}\mathrm{MS}^{2}[683]: 341(100) \\
\mathrm{MS}^{3}[683 \rightarrow 341]: 179(100), 161(23.0), 119(28.4) \\
\quad 113(28.7) \\
\mathrm{MS}^{4}[683 \rightarrow 341 \rightarrow 179]: 161(100), 135(36.3) \\
\quad 113(44.1), 89(49.0)\end{array}$ & Caffeic acid-O-hexoside \\
\hline 2 & 3.1 & - & 191 & $\begin{array}{l}\mathrm{MS}^{2}[191]: 173(46.2), 171(35.8), 127(100) \\
\quad 109(23.3), 93(38.9), 85(56.3) \\
\text { MS }^{3}[191 \rightarrow 127]: 109(100), 85.3(49.4)\end{array}$ & Quinic acid \\
\hline 3 & 4.3 & $241,298,324$ & 353 & $\begin{array}{l}\mathrm{MS}^{2}[353]: 191(100), 179(60.6), 135(18 .) \\
\mathrm{MS}^{3}[353 \rightarrow 191]: 173(49.3), 127(100) \\
\quad 111(15.1), 87(20.5), 85(17.8) \\
\text { MS }^{4}[353 \rightarrow 191 \rightarrow 127]: 109(100), 85(64.6)\end{array}$ & 3-O-Caffeoylquinic acid \\
\hline 4 & 4.6 & - & 317 & $\begin{array}{l}\mathrm{MS}^{2}[317]: 315(16.8), 225(100), 165(21.5) \\
\mathrm{MS}^{3}[317 \rightarrow 225]: 207(62.2), 165(84.0) \\
\quad 127(51.4), 125(100) \\
\mathrm{MS}^{4}[317 \rightarrow 225 \rightarrow 125]: 79(100)\end{array}$ & Unknown \\
\hline $5^{a}$ & 5.0 & $242,300,325$ & 707 & $\begin{array}{l}\mathrm{MS}^{2}[707]: 354(10.8), 353(100) \\
\mathrm{MS}^{3}[707 \rightarrow 353]: 191(100) \\
\mathrm{MS}^{4}[707 \rightarrow 353 \rightarrow 191]: 173(41.8), 127(100) \\
\quad 111(22.7), 85(20.3)\end{array}$ & 5-O-Caffeoylquinic acid \\
\hline $6^{\mathrm{a}}$ & 6.4 & $243,300,321$ & 515 & $\begin{array}{l}\mathrm{MS}^{2}[515]: 353(100), 335(28.4), 191(12.8) \\
\quad 179(34.5) \\
\operatorname{MS}^{3}[515 \rightarrow 353]: 191(100), 179(58.5), 135(22.9) \\
\mathrm{MS}^{4}[515 \rightarrow 353 \rightarrow 191]: 127(90.1), 111(58.7), 109(100)\end{array}$ & $\begin{array}{l}\text { 1,3-O-Dicaffeoylquinic } \\
\text { acid }\end{array}$ \\
\hline 7 & 7.0 & 210,304 & 337 & $\begin{array}{l}\mathrm{MS}^{2} \text { [337]: } 192(11.8), 191(100) \\
\mathrm{MS}^{3}[337 \rightarrow 191]: 173(39.1), 171(50.8), 127(100) \\
\quad 85 \text { (17.5), } 81(26.4)\end{array}$ & $\begin{array}{l}\text { cis 5-O-p-Coumaroylquinic } \\
\text { acid }\end{array}$ \\
\hline 8 & 7.4 & 327 & 367 & $\begin{array}{l}\text { MS }^{2}[367]: 191(100), 173(5.6) \\
M^{3}[367 \rightarrow 191]: 173(34.4), 111(40.5), 127 \text { (81.7), } \\
\quad 85 \text { (100) }\end{array}$ & 5-O-Feruoylquinic acid \\
\hline 9 & 7.5 & 291,320 & 533 & $\begin{array}{l}\mathrm{MS}^{2}[533]: 372(18.5), 371(100), 353(13.3) \\
\text { MS }^{3}[533 \rightarrow 371]: 353(100), 191(22.3), 173(47.7) \\
\quad 135(64.9)\end{array}$ & Caffeic acid derivative \\
\hline 10 & 7.9 & 212,305 & 675 & $\begin{array}{l}\text { MS }^{2}[675]: 338(11.1), 337(100) \\
\text { MS }^{3}[675 \rightarrow 337]: 191(100) \\
\text { MS }^{4}[675 \rightarrow 337 \rightarrow 191]: 173(44.7), 127(100) \\
\quad 109(51.1), 93(16.7), 85(82.5)\end{array}$ & $\begin{array}{l}\text { 5-O-p-Coumaroylquinic } \\
\text { acid }\end{array}$ \\
\hline 11 & 8.3 & - & 677 & $\begin{array}{l}\mathrm{MS}^{2}[677]: 516(18.0), 515(100) \\
\mathrm{MS}^{3}[677 \rightarrow 515]: 353(34.0), 341(26.1), 323(100), \\
\quad 191(48.1), 179(15.3) \\
\mathrm{MS}^{4}[677 \rightarrow 515 \rightarrow 323]: 161(100), 133(15.6)\end{array}$ & $\begin{array}{l}\text { Dicaffeoylquinic acid } \\
\text { hexoside }\end{array}$ \\
\hline 12 & 9.1 & - & 547 & $\begin{array}{l}\mathrm{MS}^{2}[547]: 312(14.7), 311(100), 293(25.1), 161(10.2) \\
\mathrm{MS}^{3}[547 \rightarrow 311]: 293(100), 221(39.1), 191(46.5), \\
\quad 161(33.8), 149(10.7) \\
\mathrm{MS}^{4}[547 \rightarrow 311 \rightarrow 293]: 207(75.8), 149(100) \\
\quad 131(54.3), 87(51.9)\end{array}$ & Unknown \\
\hline 13 & 10.0 & $254,272,340$ & 477 & $\begin{array}{l}\mathrm{MS}^{2}[477]: 316(17.0), 315(100), 300(12.7) \\
\mathrm{MS}^{3}[477 \rightarrow 315]: 301(25.5), 300(100) \\
\mathrm{MS}^{4}[477 \rightarrow 315 \rightarrow 300]: 272(47.9), 255(100) \\
\quad 216(90.0), 215(57.2), 211(78.1)\end{array}$ & Isorhamnetin-O-hexoside \\
\hline 14 & 10.8 & - & 549 & $\begin{array}{l}\mathrm{MS}^{2}[549]: 388(45.8), 387(100) \\
\mathrm{MS}^{3}[549 \rightarrow 387]: 372(49.4), 181(60.2) \\
\quad 166(77.1), 151(100) \\
\mathrm{MS}^{4}[549 \rightarrow 387 \rightarrow 151]: 136(100)\end{array}$ & Medioresinol-O-hexoside \\
\hline $15^{\mathrm{a}}$ & 12.0 & $246,300,323$ & 515 & $\begin{array}{l}\mathrm{MS}^{2}[515]: 353(100), 335(11.8), 191(10.2) \\
179(16.9), 173(38.1) \\
\operatorname{MS}^{3}[515 \rightarrow 353]: 191(43.1), 179(69.7)\end{array}$ & $\begin{array}{l}\text { 3,4-O-Dicaffeoylquinic } \\
\text { acid }\end{array}$ \\
\hline
\end{tabular}




\section{Table 3. (Continued)}

No. $t_{\mathrm{R}}(\min ) \quad \mathrm{UV} \lambda_{\max }(\mathrm{nm}) \quad[\mathrm{M}-\mathrm{H}]^{-} \mathrm{m} / \mathrm{z}$

$16^{\mathrm{a}} \quad 12.5 \quad 243,300,328$

$17^{a}$

12.9

$243,295,325$

$18 \quad 13.6$

273,332

19

$14.2 \quad 300,329$

515

2

2

$1 \quad 16.4$

$235,300,328$

$22 \quad 17.0$

$23 \quad 17.8$

$24 \quad 18.4$

$-$

219,315

25

$241,300,324$

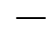

27

28

29

30

31

32
515

461

601

425

499

515

\section{5}

61

601

499
HPLC-DAD-ESI/MS ${ }^{n} \mathrm{~m} / z$ (\% base peak)

Assigned identity

173 (100), 135 (20.8)

MS $^{4}[515 \rightarrow 353 \rightarrow 173]: 155$ (57.1), 137 (38.8),

127 (33.3), 111 (100), 93 (85.6), 83 (37.8)

MS $^{2}$ [515]: 353 (100), 191 (13.8),

$\mathrm{MS}^{3}$ [515 $\left.\rightarrow 353\right]: 191(100)$

MS $^{4}[515 \rightarrow 353 \rightarrow 173]: 173$ (39.2), 127 (100),

111 (56.1), 109 (22.0)

$\mathrm{MS}^{2}$ [515]: 354 (16.5), 353 (100)

$\mathrm{MS}^{3}$ [515 $\rightarrow$ 353]: 191 (100), 179 (48.7), 135 (10.5)

$\mathrm{MS}^{4}[515 \rightarrow 353 \rightarrow 191]: 173(84.7), 127$ (97.0),

111 (46.0), 93 (56.2), 85 (100)

MS $^{2}$ [461]: 446 (68.7), 341 (12.1), 299 (100), 284 (43.6)

$\mathrm{MS}^{3}$ [461 $\rightarrow$ 299]: 285 (20.5), 284 (100)

MS $^{4}$ [461 $\left.\rightarrow 299 \rightarrow 284\right]: 284$ (62.0), 283 (58.2),

255 (100)

MS $^{2}$ [515]: 354 (11.3), 353 (100), 203 (10.8), 173 (17.5)

$\mathrm{MS}^{3}$ [515 $\rightarrow$ 353]: $191(100), 179$ (87.4), 173 (90.0)

$\mathrm{MS}^{4}$ [515 $\left.\rightarrow 353 \rightarrow 191\right]: 173$ (59.1), 127 (100),

109 (22.6), 93 (30.0)

MS $^{2}$ [601]: 557 (69.7), 515 (82.5), 395 (100), 233 (33.4)

$\mathrm{MS}^{3}$ [601 $\left.\rightarrow 395\right]: 335$ (2.7), 233 (100), 173 (13.2)

MS $^{4}[601 \rightarrow 395 \rightarrow 233]: 173(100)$

MS $^{2}$ [601]: 557 (57.3), 515 (10.6), 439 (15.5), 395 (100)

$\mathrm{MS}^{3}$ [601 $\left.\rightarrow 395\right]: 335$ (4.5), 234 (11.6), 233 (100),

$173(62.8)$

$\mathrm{MS}^{4}[601 \rightarrow 395 \rightarrow 233]: 173(100)$

MS $^{2}$ [499]: 338 (11.8), 337 (100), 163 (17.4)

$\mathrm{MS}^{3}[499 \rightarrow 337]: 191(44.3), 173(57.5)$,

$163(100)$

MS $^{4}$ [499 $\left.\rightarrow 337 \rightarrow 163\right]: 120$ (14.4), 119 (100)

MS $^{2}$ [425]: 179 (100), 135 (26.8)

$\mathrm{MS}^{3}$ [425 $\rightarrow$ 179]: 135 (100)

MS $^{2}$ [499]: 354 (13.6), 353 (100), 337 (15.7), 191 (7.2)

$\mathrm{MS}^{3}$ [499 $\rightarrow$ 353]: $191(100), 179$ (36.5), 135 (19.1)

MS $^{4}[499 \rightarrow 353 \rightarrow 191]: 173(77.6), 155$ (72.0),

127 (10.6), 95 (100)

MS $^{2}$ [529]: 368 (16.6), 367 (100), 191 (11.3)

$\mathrm{MS}^{3}$ [529 $\rightarrow$ 367]: $191(100), 173(11.3), 134$ (12.0)

MS $^{4}[529 \rightarrow 367 \rightarrow 191]: 173$ (87.9), 134 (100),

111 (28.9), 93 (24.5)

$\mathrm{MS}^{2}$ [467]: 248 (16.1), 247 (100)

$\mathrm{MS}^{3}$ [467 $\rightarrow$ 247]: 200 (84.1), 199 (96.4), 161 (64.8),

$121(100)$

$\mathrm{MS}^{2}$ [499]: 338 (17.0), 337 (100)

MS $^{3}$ [499 $\rightarrow 337$ ]: 173 (100), 164 (16.4), 163 (46.7)

$\mathrm{MS}^{4}[499 \rightarrow 337 \rightarrow 173$ ]: $93(100)$

$\mathrm{MS}^{2}$ [467]: 248 (15.4), 247 (100)

$\mathrm{MS}^{3}$ [467 $\left.\rightarrow 247\right]: 199$ (27.7), 161 (64.8), 135 (21.2), 121 (100)

MS $^{2}$ [529]: 368 (20.3), 367 (100), 349 (13.3), 191 (11.4)

$\mathrm{MS}^{3}$ [529 $\rightarrow$ 367]: $191(28.4), 173(100), 135(16.3)$

MS $^{2}$ [307]: 195 (100), 193 (44.6), 177 (35.4), 167 (14.7),

151 (14.3)

$\mathrm{MS}^{3}$ [307 $\rightarrow$ 195]: $152(100)$

$\mathrm{MS}^{2}$ [399]: 153 (100), 152 (40.2)

$\mathrm{MS}^{3}$ [399 $\rightarrow$ 153]: $109(100)$

$23.5-\quad 541$
1,5-O-Dicaffeoylquinic acid

3,5-O-Dicaffeoylquinic acid

Hispidulin-7-O-hexoside

3-O-Caffeoylquinic acid hexoside

Malonyl-3,4-O-

dicaffeoylquinic acid

Malonyl-4,5-O-

dicaffeoylquinic acid

3-O- $p$-Coumaroyl-5-Ocaffeoylquinic acid

Caffeic acid diacylated hexoside

3-O-Caffeoyl-5-O- $p$ coumaroylquinic acid

1-O-Caffeoyl-5-Oferuoylquinic acid

Brevifolin derivative

3-O-Caffeoyl-4-O- $p$ coumaroylquinic acid

Brevifolin derivative

1 or 5-O-Caffeoyl-4-Oferuloylquinic acid Unknown

Protocatechuic acid diacylated hexoside Unknown 
Table 3. (Continued)

\begin{tabular}{|c|c|c|c|c|c|}
\hline No. & $t_{\mathrm{R}}(\min )$ & UV $\lambda_{\max }(\mathrm{nm})$ & {$[\mathrm{M}-\mathrm{H}]^{-} \mathrm{m} / \mathrm{z}$} & HPLC-DAD-ESI/MS ${ }^{n} \mathrm{~m} / z$ (\% base peak) & Assigned identity \\
\hline & & & & $\begin{array}{l}\text { MS }^{3}[541 \rightarrow 497]: 479 \text { (38.1), } 327 \text { (26.5), } 279 \text { (24.2), } \\
\quad 225(100)\end{array}$ & \\
\hline 33 & 24.7 & - & 425 & $\begin{array}{l}\mathrm{MS}^{2}[425]: 180(10.4), 179(100), 135(13.9) \\
\mathrm{MS}^{3}[425 \rightarrow 179]: 136(15.5), 135(100)\end{array}$ & $\begin{array}{l}\text { Caffeic acid diacylated } \\
\text { hexoside }\end{array}$ \\
\hline 34 & 25.8 & - & 419 & $\begin{array}{l}\mathrm{MS}^{2}[419]: 219(15.4), 163(13.8), 153(100), 152(27.8) \\
\mathrm{MS}^{3}[419 \rightarrow 153]: 109(100)\end{array}$ & $\begin{array}{l}\text { Procatechuic acid } \\
\text { derivative }\end{array}$ \\
\hline 35 & 26.0 & - & 415 & $\begin{array}{l}\mathrm{MS}^{2}[415]: 371(54.2), 219(15.7), 195(46.1), 153(34.7), \\
151(100), 149(20.9), 125(17.2) \\
\mathrm{MS}^{3}[415 \rightarrow 151]: 135(100), 109(57.8)\end{array}$ & Unknown \\
\hline 36 & 27.2 & - & 409 & $\begin{array}{l}\operatorname{MS}^{2}[409]: 163(100) \\
\operatorname{MS}^{3}[409 \rightarrow 163]: 119(100)\end{array}$ & $\begin{array}{l}p \text {-Coumaric acid } \\
\text { diacylated hexoside }\end{array}$ \\
\hline $37^{\mathrm{a}}$ & 28.7 & $240,300,328$ & 677 & $\begin{array}{l}\mathrm{MS}^{2}[677]: 516(25.7), 515(100) \\
\mathrm{MS}^{3}[677 \rightarrow 515]: 353(100), 299(24.9), 191(13.4), \\
\quad 174(19.3), 173(26.5) \\
\mathrm{MS}^{4}[677 \rightarrow 515 \rightarrow 353]: 191(34.7), 173(100), 179(50.3)\end{array}$ & $\begin{array}{l}\text { 3,4,5-O-Tricaffeoylquinic } \\
\text { acid }\end{array}$ \\
\hline
\end{tabular}<smiles>[R6]OC(CC(O)(CC(=O)O)C(=O)O)O[R6]</smiles>

Quinic acid

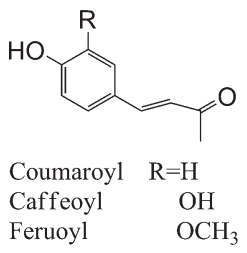<smiles>COc1c(O)cc2oc(-c3ccc(O)cc3)cc(=O)c2c1O</smiles>

Hispidulin<smiles>COC(=O)CC(=O)O</smiles><smiles>COc1cc(-c2oc3cc(O)cc(O)c3c(=O)c2O)ccc1O</smiles>

Isorhamnetin<smiles>O=C1CCc2c1oc(=O)c1cc(O)c(O)c(O)c21</smiles><smiles>COc1cc(C2OCC3C(c4cc(OC)c(O)c(OC)c4)OCC23)ccc1O</smiles>

Medioresinol

Figure 2. Chemical structures of phenolic compounds detected in Helichrysum monizii.

with UV data. Even so, five peaks remained unidentified; these are very minor components of the extract, as can be seen in the chromatogram shown in Fig. 1. Table 3 shows the analytical data: retention time $\left(t_{\mathrm{R}}\right)$, wavelength of maximum absorbance $\left(\lambda_{\max }\right)$, deprotonated molecular ions $[\mathrm{M}-\mathrm{H}]^{-}$, and major diagnostic fragment ions of the main peaks. Figure 2 represents the chemical structures of the compounds detected in Helichrysum monizii.

Quinic acid derivatives. Free quinic acid, compound $\mathbf{2}\left(t_{R}=\right.$ $2.9 \mathrm{~min}$ ), was found as a relatively important component of the extract, as it happened for the previously analysed Helichrysum subspecies (Gouveia and Castilho, 2009, 2010). A total of 19 quinic acid derivatives were found in the present study, most of them as quinic acid structures esterified with acyl moieties. The determination of the exact location of acyl groups in the quinic acid structure was achieved based on the $\mathrm{MS}^{n}$ data and taking into account the hierarchical key for the identification by LC-MS ${ }^{n}$ of quinic acid derivatives reported before (Clifford et al., 2005).

Mono-, di- and tricaffeoyquinic acids were identified by the use of standards: compounds $3\left(t_{\mathrm{R}}=4.3 \mathrm{~min}\right)$ as 3-O-caffeoylquinic acid, $5\left(t_{R}=5.0 \mathrm{~min}\right)$ as 5-O-caffeoylquinic acid, $6\left(t_{R}=6.4 \mathrm{~min}\right)$ as
1,3-O-dicaffeoylquinic acid, 15 ( $t_{R}=12.0 \mathrm{~min}$ ) as 3,4-O-dicaffeoylquinic acid, $16\left(t_{R}=12.5 \mathrm{~min}\right)$ as 1,5-O-dicaffeoylquinic acid, $17\left(t_{R}=12.9\right.$ $\mathrm{min})$ as 3,5-O-dicaffeoylquinic acid, and $\mathbf{3 7}\left(t_{\mathrm{R}}=28.7 \mathrm{~min}\right)$ as 3,4,5-Otricaffeoylquinic acid.

Compound $8\left(t_{R}=7.4 \mathrm{~min}\right)$ exhibited a $[\mathrm{M}-\mathrm{H}]^{-}$ion at $\mathrm{m} / \mathrm{z} 367$ and its $\mathrm{MS}^{2}$ fragmentation gave, as base peak, a fragment ion at $\mathrm{m} / \mathrm{z}$ 191 [quinic acid-H] ${ }^{-}$. MS ${ }^{n}$ data are consistent with those describe in literature for 5-O-feruloylquinic acid (Kuhnert et al., 2010). Compound $10\left(t_{R}=7.9 \mathrm{~min}\right)$ displayed a $[\mathrm{M}-\mathrm{H}]^{-}$ion at $\mathrm{m} / \mathrm{z} 675$. The $\mathrm{MS}^{2}$ fragmentation observed gave the main fragment ion at $\mathrm{m} / \mathrm{z} 337$, demonstrating that the deprotonated molecular ion is a dimer of an ion with $\mathrm{m} / \mathrm{z}$ of 337 . Comparison of the $\mathrm{MS}^{n}$ fragmentation data of this ion at $\mathrm{m} / \mathrm{z} 337$ to those presented by Clifford et al. (2003) revealed the characteristic fragments of 5-O- $p$ coumaroylquinic acid: an $\mathrm{MS}^{3}$ peak base at $181 \mathrm{~m} / \mathrm{z}$ and strong $\mathrm{MS}^{4}$ ions at $m / z$ 85, 127 and 172 . This substance was previously identified by our group in extracts of Helichrysum melaleucum (Gouveia and Castilho, 2010).

One more peak showed a $[\mathrm{M}-\mathrm{H}]^{-}$ion at $\mathrm{m} / \mathrm{z} 337$ and occurred at a retention time of $7.0 \mathrm{~min}$ (compound 7). This compound showed an $\mathrm{MS}^{n}$ fragmentation behaviour and UV 
spectra similar to those of 5-O-p-coumaroylquinic acid (10). Compound 7, never found in the other Helichrysum subspecies, was tentatively identified as the cis-isomer, since often hydroxycinnamic acids occur with the cinnamic group in the trans configuration, attributed to $\mathbf{1 0}$. The exposure at UV light may induce geometric isomerisation (Clifford et al., 2006a). This isomerisation can occur due to exposure to UV light during sample workup or it can be from a biosynthetic origin. In order to confirm the identification of cis-isomer, Helichysum monizii sample was irradiated with UV light for $3 \mathrm{~h}$ at room temperate and then analysed by LC-DAD-ESI/MS ${ }^{n}$. The peak area corresponding to compound $\mathbf{1 0}$ decreased substantially while the peak area of compound $\mathbf{7}$ increased, confirming $\mathbf{7}$ and $\mathbf{1 0}$ as a cis/trans pair of isomers of 5-O-p-coumaroylquinic acid.

Compound 19 occurred at a retention time of $14.2 \mathrm{~min}$ and showed UV absorption maxima at 300 and $329 \mathrm{~nm}$, which are characteristic of caffeoylquinic acid conjugates. Despite that it gave a $[\mathrm{M}-\mathrm{H}]^{-}$ion at $\mathrm{m} / \mathrm{z} 515$ and that an $\mathrm{MS}^{2}$ fragment ion at $\mathrm{m} / \mathrm{z} 353$ was formed due to the loss of a neutral moiety of $162 \mathrm{Da}$, it was not identificable as a dicaffeoylquinic acid isomer. The loss of $162 \mathrm{Da}$ can suggest either a caffeoyl loss or a hexoside loss. The former possibility was discarded since in this work five of the six possible isomers of dicaffeoylquinic acid were positively identified by reference substances with the exception being 1,4-diCQA isomer. Auxiliary fragmentation of the ion at $m / z 353$ resulted in a fragment ion at $m / z 191$, as base peak, and a very intense fragment ion at $m / z$ 179 (ca. $80 \%$ of base peak) signifying a 3-O-caffeoylquinic acid and rejecting the 1,4-diCQA hypothesis. Based on the MS $^{n}$ data, 19 was thus characterised as 3-O-caffeoylquinic acid hexoside. It was not possible to determine the exact hexoside linkage position, but it should not be directly linked to the caffeoyl moiety because no fragment ion at $m / z 323$ was detected.

Compounds $20\left(t_{R}=14.5 \mathrm{~min}\right)$ and $21\left(t_{R}=16.1 \mathrm{~min}\right)$ were identified as malonylcaffeoylquinic acids with an $[\mathrm{M}-\mathrm{H}]^{-}$ion at $\mathrm{m} / \mathrm{z}$ 601. Their $\mathrm{MS}^{2}$ spectra showed main fragment ions at $\mathrm{m} / \mathrm{z}$ $557[\mathrm{M}-\mathrm{H}-44]^{-}$and $\mathrm{m} / \mathrm{z} 515[\mathrm{M}-\mathrm{H}-86]^{-}$, due to the malonyl moiety (Zhang et al., 2007). The MS $^{2}$ base peak ion occurred at $\mathrm{m} / \mathrm{z} 395$ and corresponds to the loss of 206 Da (acetyl-caffeoyl). This type of fragmentation indicates that the malonyl group is linked to a caffeoyl moiety and not directly to the quinic acid structure. This type of compounds is not commonly found in plants but have been detected and described in our recent work with two endemic Helichrysum plants from Madeira (Gouveia and Castilho, 2009, 2010).

The dicaffeoylquinic acid part was characterised based on the fragmentation of $\mathrm{MS}^{2}$ ion at $\mathrm{m} / \mathrm{z}$ 515. Comparing the $\mathrm{MS}^{n}$ fragmentation data, UV spectra and HPLC retention times these two compounds were identified as malonyl-3,4-O-dicaffeoylquinic acid (compound 20) and malonyl-4,5-O-dicaffeoylquinic acid (compound 21).

Compounds 22 ( $\left.t_{\mathrm{R}}=17.0 \mathrm{~min}\right), 24\left(t_{\mathrm{R}}=18.4 \mathrm{~min}\right)$ and 27 $\left(t_{\mathrm{R}}=19.7 \mathrm{~min}\right)$ all gave $[\mathrm{M}-\mathrm{H}]^{-}$ions at $\mathrm{m} / \mathrm{z} 499$. For $\mathbf{2 2}$, the $M^{2}$ spectrum showed a fragment ion at $\mathrm{m} / \mathrm{z} 337$, suggesting the loss of a caffeoyl moiety $(162 \mathrm{Da})$ in the first place. The $\mathrm{MS}^{3}$ and $\mathrm{MS}^{4}$ spectra base peaks corresponded to fragment ions at $\mathrm{m} / \mathrm{z} 163$ and 119, respectively. Thus, 22 was tentatively identified as 3-O-p-coumaroyl-5-O-caffeoylquinic acid. The first substituent group eliminated from $\mathbf{2 4}$ was a coumaroyl moiety (146 Da) forming a $\mathrm{MS}^{2}$ spectrum base peak at $\mathrm{m} / \mathrm{z} 353$. The $\mathrm{MS}^{3}$ fragmentation of this ion gave as main fragment a fragment ion at $\mathrm{m} / \mathrm{z} 179$ (ca. $36 \%$ of base peak) indicating a 3-O-caffeoylquinic acid structure. Therefore, 24 was characterised as 3-O-caffeoyl-
5-O- $p$-coumaroylquinic acid. Compound 27, in a similar way of compound 22, exhibited in the $\mathrm{MS}^{2}$ spectrum, as base peak, a fragment ion at $\mathrm{m} / \mathrm{z} 337$ implicating a neutral loss of $162 \mathrm{Da}$ (caffeoyl moiety). Subsequent $\mathrm{MS}^{n}$ fragmentation of this ion gave a similar fragmentation pattern to that described for 4-O- $p$ coumaroylquinic acid (Clifford et al., 2003). Therefore, 27 was identified as 3-O-caffeoyl-4-O-p-coumaroylquinic acid (Clifford et al., 2006b).

At a retention time of $18.4 \mathrm{~min}$, besides the presence of $\mathbf{2 4}$, described above, there was a co-eluted compound, 25. This was similar to compound $29\left(t_{\mathrm{R}}=20.6 \mathrm{~min}\right)$ in originating an $[\mathrm{M}-\mathrm{H}]^{-}$ ion at $m / z$ 529. Literature reports (Han et al., 2008) mention that this deprotonated molecular ion is indicative of a caffeoylferuloylquinic acid structure. The $\mathrm{MS}^{2}$ spectrum base peak of both compounds 25 and 29 was a fragment ion at $m / z 367$ referent to the loss of $162 \mathrm{Da}$ (caffeoyl moiety). The differences observed in the $\mathrm{MS}^{3}$ spectra allowed the identification of these two isomers. The $\mathrm{MS}^{3}$ base peak was a fragment ion at $m / z 191$ for $\mathbf{2 5}$ and $m / z 173$ for 29, indicative of a 5-O-feruloylquinic acid and 4-O-feruloylquinic acid structure, respectively. The position of the caffeoyl moiety in $\mathbf{2 5}$ should be the 1-OH or 3-OH quinic acid's structure. Since it was not detected any fragment ion at $m / z 179$ with relative intensity above $50 \%$ of base peak, therefore the $3-\mathrm{OH}$ position was not a probable linkage position. Consequently, $\mathbf{2 5}$ was identified as 1-O-caffeoyl5-O-feruloylquinic acid.

Compound $\mathbf{2 9}$ has three positions available for the esterification of quinic acid with the caffeoyl group (1-OH, $3-\mathrm{OH}$ and $5-\mathrm{OH})$. Based on the $\mathrm{MS}^{2}$ fragmentation data, which revealed a fragment ion at $m / z 191$ but no fragment ion at $m / z 179$, the $1-\mathrm{OH}$ and $5-\mathrm{OH}$ positions are preferable. Also, it is more difficult for caffeoyl groups located in $3-\mathrm{OH}$ positions to be the first moiety to be lost in the $\mathrm{MS}^{2}$ fragmentation, as it was observed for 29. Distinction between 1-OH or $5-\mathrm{OH}$ position could only be achieved based on their differences of retention time or using a standard solution. Therefore, $\mathbf{2 9}$ was tentatively characterised as 1 or 5-O-caffeoyl-4-O-feruloylquinic acid (Gouveia and Castilho, 2009, 2010).

Phenolic acids. Among the several phenolic compounds detected in Helichrysum monizii four of them were characterised as caffeic acid derivatives. Compound $\mathbf{1}\left(t_{\mathrm{R}}=2.9 \mathrm{~min}\right)$ displayed an $[\mathrm{M}-\mathrm{H}]^{-}$ion at $\mathrm{m} / \mathrm{z} 683$ and in the $\mathrm{MS}^{1}$ spectrum an intense fragment ion at $m / z 341$ was also observed. The $M^{2} S^{2}$ fragmentation of the ion at $m / z 683$ gave a fragment ion at $m / z 341$, indicating that the former ion is a dimer of the last one. The ion at $\mathrm{m} / \mathrm{z} 341$ under $\mathrm{MS}^{3}$ fragmentation easily lost a neutral residue of $162 \mathrm{Da}$, originating a fragment ion at $\mathrm{m} / \mathrm{z} 179$. The ion at $\mathrm{m} / \mathrm{z} 179$ indicates a deprotonated caffeic acid ion confirmed by the MS ${ }^{4}$ ions at $\mathrm{m} / \mathrm{z} 161$ [caffeic acid $\left.-\mathrm{H}-\mathrm{H}_{2} \mathrm{O}\right]^{-}$and $\mathrm{m} / \mathrm{z} 135$ [caffeic acid $\left.-\mathrm{H}-\mathrm{CO}_{2}\right]^{-}$. The $162 \mathrm{Da}$ neutral group expelled and described in the $\mathrm{MS}^{1}$ fragmentation can be attributed to a caffeic acid or to a $\mathrm{O}$-hexoside group. It is known that $\mathrm{O}$-hexosides conjugates occur normally at lower retention times when compared to the sugar free compound. We analysed a standard solution of caffeic acid $\left(t_{R}=7.0 \mathrm{~min}\right)$ and the retention time found was higher than that of compound 1. Based on these results, we can infer this compound is more likely to be a caffeic acid-O-hexoside rather than a dicaffeic acid. The fragmentation scheme for caffeic acid-O-hexoside was recently proposed by Hossain et al. (2010).

Compound $9\left(t_{\mathrm{R}}=7.7 \mathrm{~min}\right)$ showed a $[\mathrm{M}-\mathrm{H}]^{-}$ion at $\mathrm{m} / \mathrm{z} 533$ and its $\mathrm{MS}^{n}$ fragmentation showed the characteristic fragment ions of caffeic acid such as $\mathrm{m} / \mathrm{z} 179$ and $\mathrm{m} / \mathrm{z} 135$ (caffeic acid $-\mathrm{H}-\mathrm{CO}_{2}$ ). Therefore, 9 was characterised as a caffeic acid derivative. 
Two more peaks were associated with caffeic acid derivatives, compound 23 ( $t_{R}=17.8 \mathrm{~min}$ ) and compound 33 ( $\left.t_{\mathrm{R}}=24.7 \mathrm{~min}\right)$. They exhibited $[\mathrm{M}-\mathrm{H}]^{-}$ions at $\mathrm{m} / \mathrm{z} \quad 425$ and their $\mathrm{MS}^{2}$ fragmentation led to a fragment ion at $\mathrm{m} / z 179$ (loss of $246 \mathrm{Da}$ ). The remaining structure can be attributed to a diacetylated hexose $(162+42+42$ Da; Zhao et al., 2008). Therefore, 23 and 33 were identified as caffeic acid diacetylated hexosides.

Compound $31\left(t_{\mathrm{R}}=22.4 \mathrm{~min}\right)$ gave a $[\mathrm{M}-\mathrm{H}]^{-}$ion at $\mathrm{m} / \mathrm{z} 399$. Its $\mathrm{MS}^{2}$ fragmentation led to the loss of a neutral fragment of $246 \mathrm{Da}$ (diacetylated hexoside) forming a fragment ion at $\mathrm{m} / \mathrm{z} 153$. The
$\mathrm{MS}^{3}$ fragmentation of this ion gave, as base peak, a fragment ion at $\mathrm{m} / \mathrm{z} 109$ due to the loss of $44 \mathrm{Da}$, probably $\mathrm{CO}_{2}$. These $\mathrm{MS}^{n}$ data point out to the hypothesis of a protocatechuic acid or a gentisic acid structure. The first hypothesis was supported by comparison with a standard solution of protocatechuic acid $\left(\mathrm{MS}^{n}\right.$ data not shown) where it was possible to detect the same fragments. Hence, 31 was identified as protocatechuic acid diacylated hexoside.

Compound $34\left(t_{\mathrm{R}}=25.8 \mathrm{~min}\right)$ exhibited an $[\mathrm{M}-\mathrm{H}]^{-}$ion at $\mathrm{m} / \mathrm{z}$ 419 and its $M^{2} S^{2}$ spectrum showed, as base peak, a fragment ion at $m / z 153$, resulting from the loss of $266 \mathrm{Da}$. the ion at $\mathrm{m} / \mathrm{z} 153$

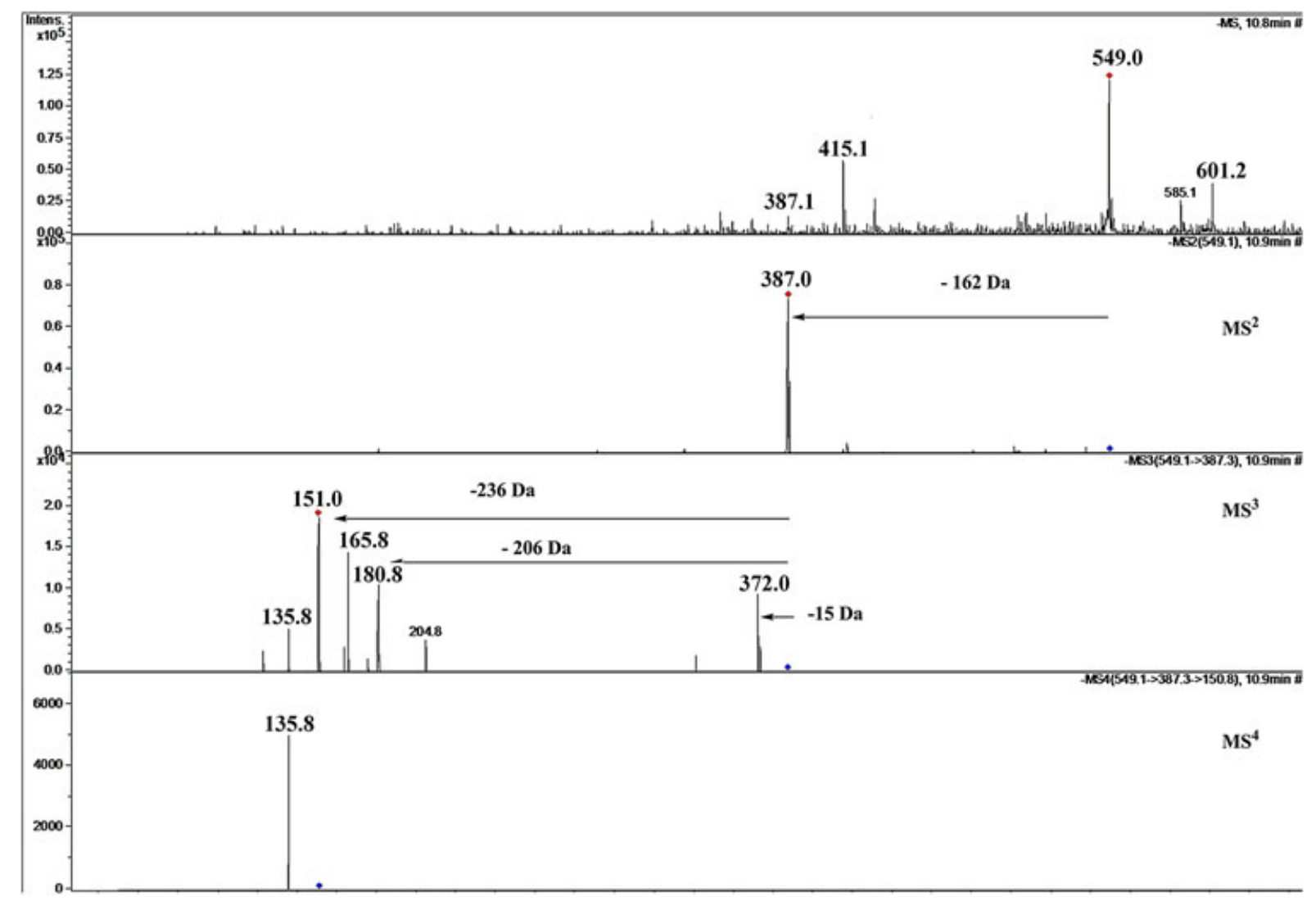

Figure 3. $\mathrm{ESI} / \mathrm{MS}^{n}$ negative mode analysis of compound 14. Sequential fragmentation, $\mathrm{MS}^{n}(n=1-4)$ of the ion at $m / z 549$.<smiles>COc1cc(C2OCC3C(c4cc(OC)c(OC5OC(CO)C(O)C(O)C5O)c(OC)c4)OCC23)ccc1O</smiles>

$[\mathrm{M}-\mathrm{H}]^{-}$

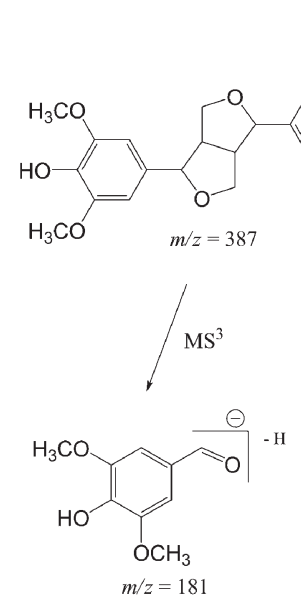

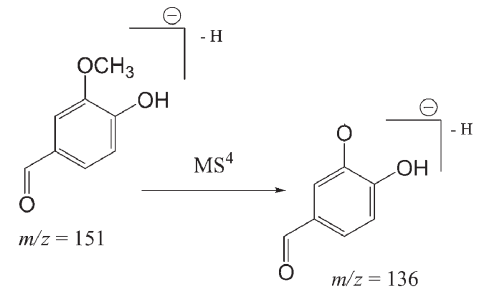

$\mathrm{MS}^{3}$

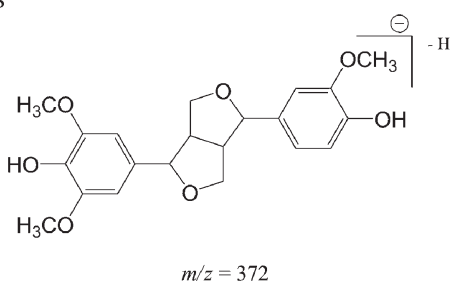

Figure 4. Proposed fragmentation pathway for compound 14. 
was characterised as [protocatechuic acid $-\mathrm{H}]^{-}$for the same reasons as mentioned for $\mathbf{3 1}$. However, the remaining structure could not be established and $\mathbf{3 4}$ was identified as a protocatechuic acid derivative.

\section{Other compounds}

Compound $13\left(t_{\mathrm{R}}=10.0 \mathrm{~min}\right)$ showed a $[\mathrm{M}-\mathrm{H}]^{-}$ion at $\mathrm{m} / \mathrm{z} 477$ and was identified as isorhamnetin-O-hexoside. This compound is a flavone and in the $\mathrm{MS}^{2}$ fragmentation the hexoside residue was lost to give the aglycone ion $\left(\mathrm{Y}_{0}^{-}\right)$at $\mathrm{m} / \mathrm{z}$ 315. Subsequent $\mathrm{MS}^{n}$ fragmentation was very similar to that described in literature for isorhamnetin (Gouveia and Castilho, 2010).

Compound $14\left(t_{\mathrm{R}}=10.8 \mathrm{~min}\right)$ displayed an $[\mathrm{M}-\mathrm{H}]^{-}$ion at $\mathrm{m} / \mathrm{z}$ 549 and under $\mathrm{MS}^{2}$ fragmentation lost a 162 Da neutral fragment originating a fragment ion at $\mathrm{m} / z$ 387. Further $\mathrm{MS}^{n}$ fragmentation gave the $\mathrm{MS}^{3}$ and $\mathrm{MS}^{4}$ base peaks at $\mathrm{m} / z 151$ and $\mathrm{m} / \mathrm{z}$ 136, respectively. Comparing these results to those described by (Eklund et al., 2008), 14 was identified as a furofuranolignan hexoside.

In this type of compounds the occurrence of the fragment ions at $m / z 151$ (guaiacyl) and/or 181 (syringyl) are due to the cleavage between the $\alpha$ - and $\beta$-position in the side chain. However, an $[\mathrm{M}-\mathrm{H}-162-15]^{-}$at $\mathrm{m} / \mathrm{z} 372$ was also observed with high intensity (ca. of base peak) that corresponds to the loss of a methoxyl group (Fig. 3). The presence of a hexoside moiety is attributed to the low retention time of this compound but its precise location could not be determined. Therefore, 14 was tentatively identified as medioresinol-O-hexoside (Fig. 4).

Compound $18\left(t_{\mathrm{R}}=13.6 \mathrm{~min}\right)$ exhibited an $[\mathrm{M}-\mathrm{H}]^{-}$ion at $\mathrm{m} / \mathrm{z}$ 461 and UV maximum absorption bands at 272 and $332 \mathrm{~nm}$. The $M^{2}$ fragmentation showed the loss of a hexoside residue, originating a fragment ion at $\mathrm{m} / \mathrm{z} 299$. This behaviour was found in our recent studies with Helichysum species and $\mathbf{1 8}$ was identified hispidulin-7-O-hexoside.

Compounds $26\left(t_{R}=19.0 \mathrm{~min}\right)$ and $28\left(t_{R}=20.2 \mathrm{~min}\right)$ possessed the same $[\mathrm{M}-\mathrm{H}]^{-}$ion at $\mathrm{m} / \mathrm{z}$ 467. The $\mathrm{MS}^{2}$ spectra showed a fragment ion at $m / z 247$, as base peak. The nature of this moiety of $220 \mathrm{Da}$ could not be identified based only on these $\mathrm{MS}^{n}$ data. For instance, the ion at $\mathrm{m} / \mathrm{z} 247$ was identified as brevifolin, a polyphenol (He and Xia, 2007). Therefore, 26 and $\mathbf{2 8}$ were identified as brevifolin derivatives.

Compound $36\left(t_{R}=27.2 \mathrm{~min}\right)$ gave a $[\mathrm{M}-\mathrm{H}]^{-}$ion at $\mathrm{m} / \mathrm{z} 409$ and under $\mathrm{MS}^{n}$ fragmentation lost a neutral fragment of $246 \mathrm{Da}$, resulting in a fragment ion at $m / z$ 163. $\mathrm{MS}^{3}$ fragmentation revealed characteristic ions of $p$-coumaric acid, for example $\mathrm{MS}^{3}$ ion at $\mathrm{m} / \mathrm{z} 119$ (loss of $\mathrm{CO}_{2}$ ) (comparison made with a standard solution). As described above, the $246 \mathrm{Da}$ fragment can be associated with a diacylated hexoside moiety. Thus, $\mathbf{3 6}$ was tentatively identified as $p$-coumaric acid diacylated hexoside.

Overall, dicaffeyolquinic acids are, by far, the most abundant components of the methanol extracts of Helychrysum monizzi and should be responsible for its exceptionally high antioxidant properties.

\section{Acknowledgements}

S. Gouveia is grateful to Fundação para a Ciência e Tecnologia (Portugal) for a Ph.D. grant SFRH/BD/24227/2005. The mass spectrometer used in this work is part of the Portuguese National Mass Spectrometry Network (contract RNEMREDE/ 1508/REM/2005) and was purchased in the framework of the National Programme for Scientific Re-equipment, with funds from POCI 2010 (FEDER) and Fundação para a Ciência e a Tecnologia. The authors are grateful to Madeira Botanical Gardens for the supply of plant material.

\section{References}

Akkol EK, Göger F, Kosar M, Baser KHC. 2008. Phenolic composition and biological activities of Salvia halophila and Salvia virgata from Turkey. Food Chem 108: 942-949.

Albayrak S, Aksoy A, Sagdic O, Hamzaoglu E. 2010. Compositions, antioxidant and antimicrobial activities of Helichrysum (Asteraceae) species collected from Turkey. Food Chem 119: 114-122.

Benzie IFF, Strain JJ. 1996. The ferric reducing ability of plasma (FRAP) as a measure of "antioxidant power": the FRAP assay. Anal Biochem 239: 70-76.

Cai Y, Luo Q, Sun M, Corke H. 2004. Antioxidant activity and phenolic compounds of 112 traditional Chinese medicinal plants associated with anticancer. Life Sci 74: 2157-2184.

Clifford MN, Johnston KL, Knight S, Kuhnert N. 2003. Hierarchical scheme for LC-MS ${ }^{n}$ identification of chlorogenic acids. J Agric Food Chem 51: 2900-2911.

Clifford MN, Knight S, Kuhnert N. 2005. Discriminating between the six isomers of dicaffeoylquinic acid by LC-MS ${ }^{n}$. J Agric Food Chem 53: 3821-3832.

Clifford MN, Zheng W, Kuhnert N. 2006a. Profiling the chlorogenic acids of aster by HPLC-MS ${ }^{n}$. Phytochem Anal 17: 384-393.

Clifford MN, Marks S, Knight S, Kuhnert N. 2006b. Characterization by LC-MS $^{n}$ of four new classes of $p$-coumaric acid-containing diacyl chlorogenic acids in green coffee beans. J Agric Food Chem 54: 4095-4101.

Eklund PC, Backman MJ, Kronberg LÅ, Smeds Al, Sjöholm RE. 2008. Identification of lignans by liquid chromatography-electrospray ionization ion-trap mass spectrometry. J Mass Spectrom 43: 97-107.

Gordon MH, Paiva-Martins F, Almeida M. 2001. Antioxidant activity of hydroxytyrosol acetate compared with that of other olive oil polyphenols. J Agric Food Chem 49: 2480-2485.

Gouveia SC, Castilho PC. 2009. Analysis of phenolic compounds from different morphological parts of Helichrysum devium by liquid chromatography with on-line UV and electrospray ionization mass spectrometric detection. Rapid Commun Mass Spectrom 23: 3939-3953.

Gouveia SC, Castilho PC. 2010. Characterization of phenolic compounds in Helichrysum melaleucum by high-performance liquid chromatography with on-line ultraviolet and mass spectrometry detection. Rapid Commun Mass Spectrom 24: 1851-1868.

Han J, Ye M, Qiao X, Xu M, Wang B-r, Guo D-A. 2008. Characterization of phenolic compounds in the Chinese herbal drug Artemisia annua by liquid chromatography coupled to electrospray ionization mass spectrometry. J Pharmaceut Biomed Anal 47: 516-525.

He Z, Xia W. 2007. Analysis of phenolic compounds in Chinese olive (Canarium album L.) fruit by RPHPLC-DAD-ESI-MS. Food Chem 105: 1307-1311.

Hossain MB, Rai DK, Brunton NP, Martin-Diana AB, Barry-Ryan C. 2010. Characterization of phenolic composition in Lamiaceae spices by LC-ESI-MS/MS. J Agric Food Chem 58: 10576-10581.

Katalinic V, Mozina SS, Skroza D, Generalic I, Abramovic H, Milos M, Ljubenkov I, Piskernik S, Pezo I, Terpinc P and others. 2010. Polyphenolic profile, antioxidant properties and antimicrobial activity of grape skin extracts of 14 Vitis vinifera varieties grown in Dalmatia (Croatia). Food Chem 119: 715-723.

Kaufman PB, Cseke LJ, Warber S, Duke JA, Brielmann HL. 1999. Natural Products Isolation from Plants, 2nd edn. CRC Press: Boca Raton, FL.

Kim D-O, Lee CY. 2004. Comprehensive study on vitamin C equivalent antioxidant capacity (VCEAC) of various polyphenolics in scavenging a free radical and its structural relationship. Crit Rev Food Sci 44: 253-273.

Kuhnert N, Jaiswal R, Matei MF, Sovdat T, Deshpande S. 2010. How to distinguish between feruloyl quinic acids and isoferuloyl quinic acids by liquid chromatography/tandem mass spectrometry. Rapid Commun Mass Spectrom 24: 1575-1582.

Li BB, Smith B, Hossain MM. 2006. Extraction of phenolics from citrus peels: I. Solvent extraction method. Sep Purif Technol 48: 182-188. 
Mabry TJ, Markham KR, Thomas MB. 1970. The ultraviolet spectra of flavones and flavonols, isoflavones, dihydroxyflavonols. In The Systematic Identification of Flavonoids. Springer: New York.

Parejo I, Viladomat F, Bastida J, Rosas-Romero A, Flerlage N, Burillo J, Codina C. 2002. Comparison between the radical scavenging activity and antioxidant activity of six distilled and nondistilled Mediterranean herbs and aromatic plants. J Agric Food Chem 50: 6882-6890.

Re R, Pellegrini N, Proteggente A, Pannala A, Yang M, Rice-Evans C. 1999. Antioxidant activity applying an improved ABTS radical cation decolorization assay. Free Radic Biol Med 26: 1231-1237.

Siddhuraju P. 2007. Antioxidant activity of polyphenolic compounds extracted from defatted raw and dry heated Tamarindus indica seed coat. LWT Food Sci Technol 40: 982-990.

Siddhuraju P, Becker K. 2003. Studies on antioxidant activities of mucuna seed (Mucuna pruriens var utilis) extract and various non-protein amino/imino acids through in vitro models. J Sci Food Agric 83: 1517-1524.
Silva MM, Santos MR, Caroço G, Rocha R, Justino G, Mira L. 2002. Structure-antioxidant activity relationships of flavonoids: a reexamination. Free Radical Res 36: 1219-1227.

Singleton VL, Orthofer R, Lamuela-Raventós RM. 1999. Analysis of total phenols and other oxidation substrates and antioxidants by means of Folin-Ciocalteu reagent. In Lester P (ed.), Methods in Enzymology. Academic Press: London; 152-178.

Zhang Y, Shi P, Qu H, Cheng Y. 2007. Characterization of phenolic compounds in Erigeron breviscapus by liquid chromatography coupled to electrospray ionization mass spectrometry. Rapid Commun Mass Spectrom 21: 2971-2984.

Zhao H-Y, Sun J-H, Fan M-X, Fan L, Zhou L, Li Z, Han J, Wang B-R, Guo D-A. 2008. Analysis of phenolic compounds in Epimedium plants using liquid chromatography coupled with electrospray ionization mass spectrometry. J Chromatogr A 1190: 157-181.

Zheng W, Wang SY. 2001. Antioxidant activity and phenolic compounds in selected herbs. J Agric Food Chem 49: 5165-5170. 